\title{
First report of grapevine leafroll-associated virus 3 in wild vines (Vitis vinifera subsp. sylvestris) in Tunisia
}

\author{
Naima Mahfoudhi ${ }^{1}$ (D) Ilhem Selmi ${ }^{1} \cdot$ Manel Elair $^{1} \cdot$ Guiseppe Garfi $^{2} \cdot$ Salvatore Pasta $^{2} \cdot$ Francesco Carimi $^{2}$. \\ Davide Pacifico $^{2}$
}

Received: 17 March 2021 / Accepted: 15 April 2021 / Published online: 20 April 2021

○ Società Italiana di Patologia Vegetale (S.I.Pa.V.) 2021

Keywords Wild grapevine $\cdot$ GLRaV-3 $\cdot$ Tunisia

Wild grapevines (Vitis vinifera subp. sylvestris) form scattered populations mostly in the Northwest and Northeast of Tunisia. Wild grapevines may represent natural reservoirs for pathogens including viruses and can play an important role in their spread to cultivated grapevines. Previous studies showed the presence of grapevine rupestris stem pittingassociated virus (GRSPaV) and grapevine virus A (GVA) in Tunisian wild grapevines (Selmi et al. 2017, 2018). Grapevine leafroll-associated virus $3(\mathrm{GLRaV}-3)$ belongs to the genus Ampelovirus, in the family Closteroviridae, has a worldwide distribution, and is widely distributed in Tunisian vineyards. To study the presence of GLRaV-3 in wild grapevines, a survey was carried out in the mountain forests of northern Tunisia. Dormant canes from 68 accessions (male and female specimens) were collected and tested for the presence of GLRaV-3 by RT-PCR using specific primers (Ling et al. 1998) to amplify a $546 \mathrm{bp}$ fragment of the heatshock protein 70 homolog (HSP70h) gene. Results showed that $10.3 \%$ ( 7 of 68 ) of the samples tested were infected by GLRaV-3. To confirm the presence of GLRaV-3 in wild Tunisian grapevines, RT-PCR amplicons from two positive accessions were sequenced and sequences were compared with those available in GenBank. The Tunisian GLRaV-3 isolates VS25 (HG996442) and VS50 (HG996439) showed respectively $96 \%$ and $98 \%$ nucleotide sequence identity

Naima Mahfoudhi

nmahfoudhi@yahoo.fr

1 Laboratoire de Protection Des Végétaux, Université de Carthage, Institut National de La Recherche Agronomique de Tunisie, Rue Hedi Karray, 1004 ElMenzah, LR16INRAT04 Tunis, Tunisia

2 Istituto di Bioscienze e BioRisorse (IBBR), Consiglio Nazionale delle Ricerche (CNR), Corso Calatafimi 414, 90129 Palermo, Italy with isolate NY1 (AF037268) representing Group I. To our knowledge, this is the first report of GLRaV-3 in wild grapevines in Tunisia.

Data availability The sequencing data generated in this study were deposited in the Genbank and will be freely available to any researcher.

\section{Declarations}

Informed consent All authors have approved the submission of this manuscript.

Conflict of interest The authors declare that they have no conflict of interest.

\section{References}

Ling KS, Zhu HY, Drong RF, Slightom JL, McFerson JR, Gonsalves D (1998) Nucleotide sequence of the 3'-terminal two thirds of the grapevine leafroll-associated virus-3 genome reveals a typical monopartite closterovirus. J Gen Virol 79:1299-1307

Selmi I, Pacifico D, Ben Slimane Harbi M, Garfi G, Carimi F, Mahfoudhi N (2018) First report of Grapevine rupestris stem pitting-associated virus in wild grapevines (Vitis vinifera subsp. sylvestris) in Tunisia. Plant Dis 102:458

Selmi I, Pacifico D, Lehad A, Garfî G, Carimi F, Mahfoudhi N (2017) Occurrence of Grapevine virus A in wild grapevines (Vitis vinifera subsp. sylvestris) in Tunisia. J Plant Pathol 99(3):817

Publisher's Note Springer Nature remains neutral with regard to jurisdictional claims in published maps and institutional affiliations. 